\title{
OTIMIZAÇÃO DE PROTOCOLOS DE EXTRAÇÃO DE RNA EM DIFERENTES TECIDOS DE MILHO
}

\author{
BRENDA NEVES PORTO ${ }^{1}$, PAULO CÉSAR MAGALHÃES ${ }^{2}$, NÁDIA ALVES CAMPOS ${ }^{1}$, \\ JOSÉ DONIZETI ALVES ${ }^{1}$ e MARCELO MURAD MAGALHÃES ${ }^{1}$
}

${ }^{1}$ Universidade Federal de Lavras, Departamento de Biologia, Setor de Fisiologia Vegetal, Cx. Postal 37, Campus Universitário, CEP: 37200-000 Lavras, MG, Brasil, E-mail: brendabio@, hotmail.com,nadialvesnep@hotmail.com,jdalves@dbi.ufla.br,mmurad@ufla.br

${ }^{2}$ Embrapa Milho e Sorgo, Cx. Postal 151, CEP: 37701-970 Sete Lagoas, MG, Brasil, E-mail: pcesar@cnpms.embrapa.br

Revista Brasileira de Milho e Sorgo, v.9, n.2, p.189-200, 2010

RESUMO - Neste trabalho, foram testados cinco métodos de extração de RNA (CTAB microextração, Concert ${ }^{\mathrm{TM}}$ Invitrogen, Concert ${ }^{\mathrm{TM}}$ Adaptado, TRI Reagente ${ }^{\circledR}$ Sigma e TRI Reagente ${ }^{\circledR}$ Adaptado), em dois diferentes tecidos de milho (mesocótilo e raiz), com o objetivo de estabelecer um método eficiente de extração de RNA, visando posteriormente estudos de expressão gênica. Observou-se que o método Concert,utilizando o protocolo adaptado, foi o mais eficiente para a extração de RNA de ambos os tecidos de plântulas de milho, originando $2351,35 \mu \mathrm{g}$ por $100 \mathrm{mg}$ de tecido para mesocótilo e 893,75 $\mu \mathrm{g}$ por $100 \mathrm{mg}$ de tecido para raiz, considerando tanto a quantidade como a qualidade das amostras, podendo ser submetidas às etapas posteriores de tratamento com DNAse e construção de cDNA para estudos de expressão gênica. Pôde-se observar que pequenas modificações nos protocolos, como, por exemplo, mudança no tempo e na posição dos tubos durante a incubação e o incremento de duas lavagens com clorofórmio, podem melhorar muito tanto a qualidade quanto a quantidade do RNA extraído.

Palavras-chave: Ácidos nucleicos, Zea mays, mesocótilo, raiz. 


\title{
OPTIMIZATION OF RNA EXTRACTION PROTOCOLS USING DIFFERENT MAIZE TISSUES
}

\begin{abstract}
Five RNA extraction methods were tested (CTAB micro extraction, Concert $^{\mathrm{TM}}$ - Invitrogen; Concert ${ }^{\mathrm{TM}}$ adapted; TRI Reagent ${ }^{\circledR}$ - Sigma; TRI Reagent ${ }^{\circledR}$ adapted) using two different maize tissues (mesocotyl and root), objectifying to establish an efficient method to extract RNA to be later used in gene expression studies. Concert ${ }^{\mathrm{TM}}$ method using the adapted protocol was the most efficient for RNA extraction from both tissues of maize seedlings, originating $2351.35 \mu \mathrm{g}$ per $100 \mathrm{mg}$ of mesocotyl and 893.75 $\mu \mathrm{g}$ per $100 \mathrm{mg}$ of roots, considering both quantity and quality of the extracted RNA. Thus, samples can be submitted to further steps, like DNAse treatment and cDNA synthesis, for gene expression studies. Results showed that small modifications like change in time and tube positioning during incubation and the use of two extra chloroform washings can improve RNA amount, quality and integrity, from different tissues. These modifications might be used in researches on gene expression.
\end{abstract}

Key words: Nucleic Acids, Zea mays, mesocotyl, root.

Para a utilização de técnicas sensíveis de biologia molecular, como o estudo de genes diferencialmente expressos, incluindo transcrição reversa, PCR quantitativo em tempo real (qrtPCR), construção de bibliotecas de cDNA ou análises de microarray, é necessária a obtenção de um RNA de boa qualidade e em quantidades adequadas (Cardilho et al., 2006).

Em plantas, a presença de compostos secundários, polissacarídeos e polifenóis em grande quantidade tem imposto, durante as extrações, sérias limitações para a obtenção de RNA de boa qualidade. Portanto, adaptações nas metodologias atuais de extração desses polinucleotídeos para os diferentes tecidos e espécies de plantas, caso não existam, sempre se fazem necessárias e são comuns na literatura (Geuna et al., 1998; Salzman et al., 1999; Azevedo et al., 2003).

Alguns dos protocolos mais usados são os que utilizam polivinilpirrolidona (PVP) solúvel, precipitação com etanol, extração com fenol, precipitação com cálcio ou brometo de cetil trimetil amônio (CTAB) (Salzman et al., 1999; Komjanc et al., 1999; Dal Cin et al., 2005; Meisel et al., 2005). Nas técnicas mais comuns, geralmente são acrescentadas substâncias para eliminar contaminantes, bem como o uso de 
solventes orgânicos, como o clorofórmio e o fenol, que têm como função separar o RNA das proteínas. É de uso comum também a adição de guanidina thiocianeto, que é usada para inibir a atividade de RNAses (Chomczynski \& Sacchi, 1987; Valenzuela-Avendaño et al., 2005).

Diante do exposto, este trabalho teve como objetivo padronizar um método de extração de RNA de dois tecidos de milho que seja eficiente, apresentando extrações com alto rendimento, pureza e integridade desse ácido nucleico, visando posteriores análises moleculares relacionadas à expressão gênica.

$\mathrm{O}$ experimento foi realizado na Universidade Federal de Lavras (UFLA), situada no município de Lavras, MG, Brasil. A germinação das sementes foi realizada no setor de Fisiologia Vegetal e as atividades laboratoriais de biologia molecular desenvolvidas no Laboratório Central de Biologia Molecular (LCBM).

Para a realização do presente trabalho, foram utilizadas plântulas de milho BRS 4154 (Saracura), Ciclo 18, desenvolvida pela Embrapa Milho e Sorgo. Essa variedade de milho tem como característica principal, além da produtividade, alta tolerância a períodos intermitentes de encharcamento do solo.

Anteriormente à extração de RNA total, todos os materiais utilizados para extração foram tratados com solução diethilpirocarbonato (DEPC) a 0,5\%, para inativar RNAses, e as soluções utilizadas foram preparadas com água destilada autoclavada RNAse-free.
Inicialmente, foram germinadas, em rolos de papel germitest, vinte e cinco cariopses previamente tratadas com 1 g.L $\mathrm{L}^{-1}$ do fungicida comercial CAPTAN 50\%, os quais permaneceram em câmara de germinação úmida a $25 \pm 2^{\circ} \mathrm{C}$, no escuro, por quatro dias. Após esse período, foram coletadas amostras da região mediana tanto do mesocótilo quanto da raiz e colocadas em nitrogênio líquido e, em seguida, armazenadas em freezer $-80^{\circ} \mathrm{C}$ até as análises.

As amostras de mesocótilo e raiz foram submetidas a cinco diferentes métodos de extração de RNA: CTAB microextração (Chang et al., 1993), Concert ${ }^{\mathrm{TM}}$ Invitrogen, Concert ${ }^{\mathrm{TM}}$ Adaptado, TRI Reagente ${ }^{\circledR}$ Sigma e TRI Reagente ${ }^{\circledR}$ Adaptado.

O método de extração de RNA com CTAB foi descrito por Chang et al. (1993) e adaptado para microextração neste experimento. Em cada microtubo, contendo $100 \mathrm{mg}$ do material macerado em nitrogênio líquido, foram adicionados $800 \mu \mathrm{L}$ de tampão de extração $[2 \%(\mathrm{p} / \mathrm{v})$ CTAB (cethyltrimethylammonium bromide), 2\% (p/v) PVP, $100 \mathrm{mM}$ de Tris-HCL, $25 \mathrm{mM}$ de EDTA, $20 \mathrm{mM}$ de $\mathrm{NaCl}$ ] e $100 \mu \mathrm{L}$ de $\beta$-mercaptoetanol. Após as amostras serem incubadas a $65^{\circ} \mathrm{C}$, por 20 minutos, foram adicionados $900 \mu \mathrm{L}$ de clorofórmio e, em seguida, agitadas e centrifugadas por dez minutos, a $11.000 \mathrm{~g}$, à temperatura de $4^{\circ} \mathrm{C}$. O sobrenadante foi transferido para novo tubo e adicionado mesmo volume de clorofórmio, seguido de homogeneização e novamente centrifugação por dez minutos, a $11.000 \mathrm{~g}$, à temperatura de 
$4^{\circ} \mathrm{C}$. A fase aquosa foi transferida para um novo tubo, e adicionado Cloreto de Lítio a $12 \mathrm{M}$, para uma concentração final de 2,5 M. As amostras foram deixadas durante a noite a $4^{\circ} \mathrm{C}$, para a precipitação. Posteriormente, as amostras foram centrifugadas durante 30 minutos, a $13.200 \mathrm{~g}$, à temperatura de $4^{\circ} \mathrm{C}$ e o sobrenadante descartado. O pellet formado foi lavado com Cloreto de Lítio a 2,5 M, seguido de nova centrifugação por 15 minutos, a $13.200 \mathrm{~g}$, à temperatura de $4^{\circ}$ C. Em seguida, o sobrenadante foi descartado, o pellet lavado com $1000 \mu \mathrm{L}$ de etanol 70\% (v/v) e centrifugado por dez minutos, a $11.000 \mathrm{~g}$, à temperatura de $4^{\circ} \mathrm{C}$. Finalmente, o sobrenadante foi descartado e o líquido residual removido do tubo com a pipeta. O RNA foi ressuspendido em $20 \mu \mathrm{L}$ de água Milli-Q autoclavada. As amostras foram armazenadas a $-20^{\circ} \mathrm{C}$.

O protocolo de extração de RNA com Concert foi realizado de acordo com o manual: Concert ${ }^{\mathrm{TM}}$ Plant RNA Reagent (Invitrogen). Foram macerados $100 \mathrm{mg}$ de tecido em nitrogênio líquido e transferidos para microtubos, juntamente com $500 \mu \mathrm{L}$ do reagente Concert gelado $\left(4^{\circ} \mathrm{C}\right)$ e homogeneizados em vórtex. Em seguida, os tubos foram deixados à temperatura ambiente por cinco minutos. Após esse período, o material foi submetido à centrifugação por dois minutos, à temperatura ambiente, com velocidade de $12.000 \mathrm{~g}$, e o sobrenadante foi transferido para um novo tubo. Em seguida, foram adicionados $100 \mu \mathrm{L}$ de $\mathrm{NaCl} 5 \mathrm{M}$ e as amostras homogeneizadas em vórtex, por cinco segundos. Na sequência, foram adicionados $300 \mu \mathrm{L}$ de clorofórmio e os tubos foram submetidos à inversão por $5 \mathrm{X}$. Para separar as fases, as amostras foram submetidas à centrifugação de $12.000 \mathrm{~g}$, durante dez minutos, à temperatura de $4^{\circ} \mathrm{C}$, e a fase aquosa superior foi transferida para um novo tubo. Em seguida, foi adicionado um volume equivalente à fase aquosa de isopropanol gelado e homogeinizados em vórtex, durante cinco segundos. As amostras foram mantidas à temperatura ambiente por dez minutos e posteriormente submetidas à centrifugação também por dez minutos a $4^{\circ} \mathrm{C}$ e 12.000 g. O sobrenadante foi descartado, o pellet foi lavado com $1 \mathrm{~mL}$ de etanol $75 \%$ gelado e os tubos foram submetidos à centrifugação por 1 minuto, à temperatura ambiente (12.000 g). O líquido residual foi removido do tubo com a pipeta e o RNA foi ressuspendido em $20 \mu \mathrm{L}$ de água Milli-Q autoclavada. As amostras foram armazenadas a $-20^{\circ} \mathrm{C}$.

Esse mesmo protocolo sofreu algumas adaptações para melhorar as extrações de RNA. Para cada microtubo contendo $100 \mathrm{mg}$ de tecido macerado, foram adicionados $500 \mu \mathrm{L}$ do reagente Concert gelado $\left(4^{\circ} \mathrm{C}\right)$ e homogeneizados em vórtex por dois minutos. Em seguida, os tubos foram incubados por dez minutos, à temperatura ambiente, deixados horizontalmente para maximizar a extração do RNA. Após esse período, o material foi submetido à centrifugação por cinco minutos à temperatura de $4^{\circ} \mathrm{C}$, com velocidade máxima e o sobrenadante foi transferido para novos microtubos, os quais já continham $100 \mu \mathrm{L}$ de $\mathrm{NaCl} 5 \mathrm{M}$ e posteriormente 
foram adicionados mais $300 \mu \mathrm{L}$ de clorofórmio gelado e levados ao vórtex por 1 minuto, para homogeneizar. Para separar as fases, as amostras foram submetidas à centrifugação de $12.000 \mathrm{~g}$, durante dez minutos, à temperatura de $4^{\circ} \mathrm{C}$, e a fase aquosa superior foi transferida para um novo microtubo. Em seguida, foi adicionado um volume equivalente à fase aquosa de isopropanol gelado, aproximadamente $550 \mu \mathrm{L}$ e os microtubos foram homogeneizados por inversão. As amostras foram deixadas por 30 minutos no freezer, a $-20^{\circ} \mathrm{C}$, para precipitação e, logo após, foram centrifugadas por 25 minutos, a $4^{\circ} \mathrm{C}$, na velocidade de 12.000 g. O sobrenadante foi descartado, o pellet lavado com $600 \mu \mathrm{L}$ de etanol $75 \%$ gelado e os microtubos foram submetidos à centrifugação por cinco minutos à temperatura de $4^{\circ} \mathrm{C}$, na velocidade de $12.000 \mathrm{~g}$. O líquido residual foi removido dos tubos com a pipeta, os quais ficaram em estufa a $37^{\circ} \mathrm{C}$, até secar. Em seguida, o RNA foi ressuspendido em $20 \mu \mathrm{L}$ de água Milli-Q autoclavada e as amostras foram armazenadas no freezer a $-20^{\circ} \mathrm{C}$.

Já o método de extração de RNA com TRI Reagente ${ }^{\circledR}$ Sigma foi realizado de acordo com as especificações do manual. Foram macerados $100 \mathrm{mg}$ de tecido vegetal em nitrogênio líquido e colocados em microtubos de 1,5 mL, nos quais foram imediatamente adicionados $1 \mathrm{~mL}$ do TRI Reagente $^{\circledR}$ (Sigma) e levados ao vórtex. Em seguida, esses microtubos foram centrifugados por dez minutos a $4^{\circ} \mathrm{C}$, na velocidade de 12.000 g, e o sobrenadante resultante da centrifugação foi transferido para novos microtubos. Após a centrifugação, o material foi incubado por cinco minutos, à temperatura ambiente, e, em seguida adicionados $200 \mu \mathrm{L}$ de clorofórmio e homogeneizado por 15 segundos. As amostras foram incubadas por 15 minutos, em temperatura ambiente, e, logo em seguida, centrifugadas por 15 minutos, a $4^{\circ} \mathrm{C}$, na velocidade de $12.000 \mathrm{~g}$. A fase incolor resultante foi transferida para novos microtubos e a eles foram adicionados $500 \mathrm{uL}$ de isopropanol e levados ao vórtex. Posteriormente, as amostras foram incubadas por uma hora, a $-20^{\circ}$ C, para precipitação do RNA. Após esse período as amostras foram centrifugadas por dez minutos, a $4^{\circ} \mathrm{C}$, e velocidade de $12.000 \mathrm{~g}$. O sobrenadante foi descartado e adicionado $1 \mathrm{~mL}$ de etanol $75 \%$ para lavar o pellet. As amostras foram, então, centrifugadas por cinco minutos, a $4^{\circ} \mathrm{C}$, com velocidade de $7.500 \mathrm{~g}$. Todo o álcool $75 \%$ foi descartado e as amostras ficaram secando por dez minutos. Na sequência, o RNA foi ressuspendido em $20 \mu \mathrm{L}$ de água Milli-Q autoclavada.

Esse protocolo também sofreu algumas adaptações. Todo o material utilizado para extração do RNA foi colocado em nitrogênio líquido, antes de começar a extração, para melhorar a eficiência do processo. Para cada $100 \mathrm{mg}$ de tecido previamente macerado em nitrogênio liquido, foi adicionado $1 \mathrm{~mL}$ do reagente TRI Reagente ${ }^{\circledR}$ (Sigma) e a amostra submetida ao vórtex por um minuto. Em seguida, as amostras foram deixadas à temperatura ambiente por cinco minutos e adicionados 120 $\mu \mathrm{L}$ de clorofórmio para homogenização em vórtex, por 20 segundos. Logo após, as amostras 
foram centrifugadas por 40 minutos à temperatura de $4^{\circ} \mathrm{C}$ a $8.000 \mathrm{~g}$, e o sobrenadante resultante dessa centrifugação foi transferido para novos microtubos, aos quais foram adicionados $600 \mu \mathrm{L}$ de isopropanol e homogenizados por inversão por três vezes e colocados para precipitar por uma hora no gelo. Na sequência, ocorreu uma nova centrifugação nas mesmas condições anteriores, só que dessa vez o sobrenadante foi descartado e o pellet lavado com $400 \mu \mathrm{L}$ de etanol 75\%. As amostras ficaram dez minutos em temperatura ambiente e logo após foram centrifugadas por 15 minutos, na velocidade de $8.000 \mathrm{~g}$, em temperatura ambiente. Todo o álcool foi descartado, o excesso retirado com pipeta e os microtubos mantidos invertidos por dois minutos. Em seguida, o RNA foi ressuspendido em $60 \mu \mathrm{L}$ de água DEPC autoclavada e incubado no gelo por uma hora. Logo após, houve uma centrifugação por 15 minutos, a $4^{\circ} \mathrm{C}$, na velocidade de $8.000 \mathrm{~g}$, o sobrenadante transferido para novos microtubos e a precipitação foi feita com $6 \mu \mathrm{L}$ de de acetado de sódio $3 \mathrm{M} \mathrm{e}$ isopropanol mesmo volume durante uma hora, no gelo. Em seguida, ocorreu centrifugação por 20 minutos, a $14.000 \mathrm{~g}$, a $4^{\circ} \mathrm{C}$, o sobrenadante foi descartado e o pellet lavado com $400 \mu \mathrm{L}$ de etanol 75\%. Em seguida, os microtubos foram deixados por dez minutos à temperatura ambiente e depois centrifugados durante 15 minutos, a 8000 g. Logo após, o etanol $75 \%$ foi descartado e seu excesso retirado com pipeta. Os microtubos ficaram invertidos por dois minutos e, em seguida, o RNA foi ressuspendido em 60 $\mu \mathrm{L}$ de água DEPC autoclavada e incubados por uma hora, no gelo. Logo ápos, os microtubos foram centrifugados durante 15 minutos, o sobrenadante transferido para novos microtubos e a precipitação foi realizada com $6 \mu \mathrm{L}$ de acetato de sódio $3 \mathrm{M}$ e $6 \mu \mathrm{L}$ isopropanol, durante uma hora, no gelo. Por fim, após uma centrifugação por 20 minutos, o sobrenadante foi descartado e o pellet de RNA foi ressuspendido em $20 \mu \mathrm{L}$ de água Milli-Q autoclavada.

Para a avaliação da integridade das amostras extraídas, o RNA foi submetido a eletroforese em gel de agarose $1,2 \%(\mathrm{~m} / \mathrm{v})$, corado com $1 \mu \mathrm{L}$ de brometo de etídio $(0,5 \mu \mathrm{g} / \mathrm{mL})$, posteriormente visualizado sob luz ultravioleta e a imagem captada pelo fotodocumentador EDAS $290\left(\operatorname{Kodak}^{\circledR}\right)$. As amostras foram quantificadas em espectrofotômetro (Nanodrop ${ }^{\circledR}$ Espectrophotometer ND-1000) a $A_{260}$ nm, com o objetivo de determinar a quantidade e a qualidade (integridade).

$\mathrm{O}$ experimento foi conduzido em delineamento inteiramente casualizado, com três repetições, compostas por 100 plântulas. Cada protocolo foi feito com três repetições biológicas.

Para a avaliação de pureza, são observadas as relações entre as absorbâncias A260/280 e A260/A230, que indicam, respectivamente, possíveis contaminações por proteínas e polissacarídeos ou polifenóis (Logemann et al., 1987; Manning, 1991;). Para considerar as amostras isentas de contaminação esses valores devem se situar entre 2,1 e 1,8, respectivamente. Quanto à quantidade, o ideal seria uma concentração de, no mínimo, 500 ng/ $\mu \mathrm{L}$ (Asif 
et al., 2006). É muito importante, para o sucesso do isolamento de RNA, que polissacarídeos e polifenóis, encontrados naturalmente em diferentes quantidades nos diversos tecidos vegetais, não se liguem aos ácidos nucléicos, interferindo na quantidade, na qualidade e na integridade da amostra (Suzuki et al., 2005; Zamboni et al., 2008).

Para os procedimentos de extração, o mesmo material coletado foi utilizado e a mesma quantidade de tecido foi padronizada nas microextrações $(100 \mathrm{mg})$.

As concentrações dos RNAs e as relações de pureza resultantes de todos os métodos de extração avaliados estão dispostas na Tabela 1.

Ao comparar os métodos descritos no trabalho, pode-se observar que os métodos que foram adaptados, tanto o Concert ${ }^{\mathrm{TM}}$ quanto o TRI Reagente ${ }^{\circledR}$, apresentaram uma melhor qualidade das amostras. Esses métodos apresentaram os melhores resultados de concentração, com as relações de absorbância ideais, determinando amostras com pouca ou nenhuma contaminação com proteínas e polifenóis. No caso do Concert ${ }^{\mathrm{TM}}$, isso pode estar relacionado à presença de $\beta$-mercaptoetanol em sua composição que tem função de reduzir substâncias antioxidantes e compostos fenólicos (Jaakola, 2001), juntamente com as modificações de protocolo realizadas em relação ao protocolo sugerido pelo fabricante. Já no caso do TRI Reagente ${ }^{\circledR}$, mesmo com a presença de fenol na sua composição, que é capaz de causar danos a cauda poli-A do
mRNA extraído (Azevedo et al., 2003), não houve interferência nas extrações de RNA nos tecidos analisados, justamente pela utilização das modificações no protocolo, o que não aconteceu em trabalhos realizados por Paula (2009), com café, onde esse método apresentou, para a maioria dos tecidos testados (raiz, folha, flor e fruto), muita contaminação nas amostras de RNA, com exceção da folha. Sendo assim, considerado pela autora um método ineficiente para obter RNA de boa qualidade de café.

Os métodos CTAB, Concert ${ }^{\mathrm{TM}}$ e TRI Reagente ${ }^{\circledR}$ apresentaramamostras contaminadas com proteínas e polifenóis, segundo a relação dos valores de absorbância, que representaram valores menores aos recomendados. $\mathrm{Na}$ extração realizada utilizando os métodos CTAB e Concert ${ }^{\mathrm{TM}}$, também é observado um baixo rendimento entre os tecidos, o que não acontece com o método TRI Reagente ${ }^{\circledR}$, no qual, mesmo com contaminação o rendimento das amostras de ambos os tecidos, está dentro das necessidades requeridas na pesquisa científica (Tabela 1).

O método $\mathrm{CTAB}$, mesmo utilizando substâncias que reduzem compostos fenólicos e precipitação com cloreto de lítio para reter substâncias protéicas auxiliando na descontaminação das amostras, não apresentou resultado satisfatório nos tecidos analisados, como pode ser observado na Tabela 1. Entretanto, em trabalhos realizados por Paula (2009), com raiz, folha, flor e fruto de café, esse foi o melhor método encontrado 


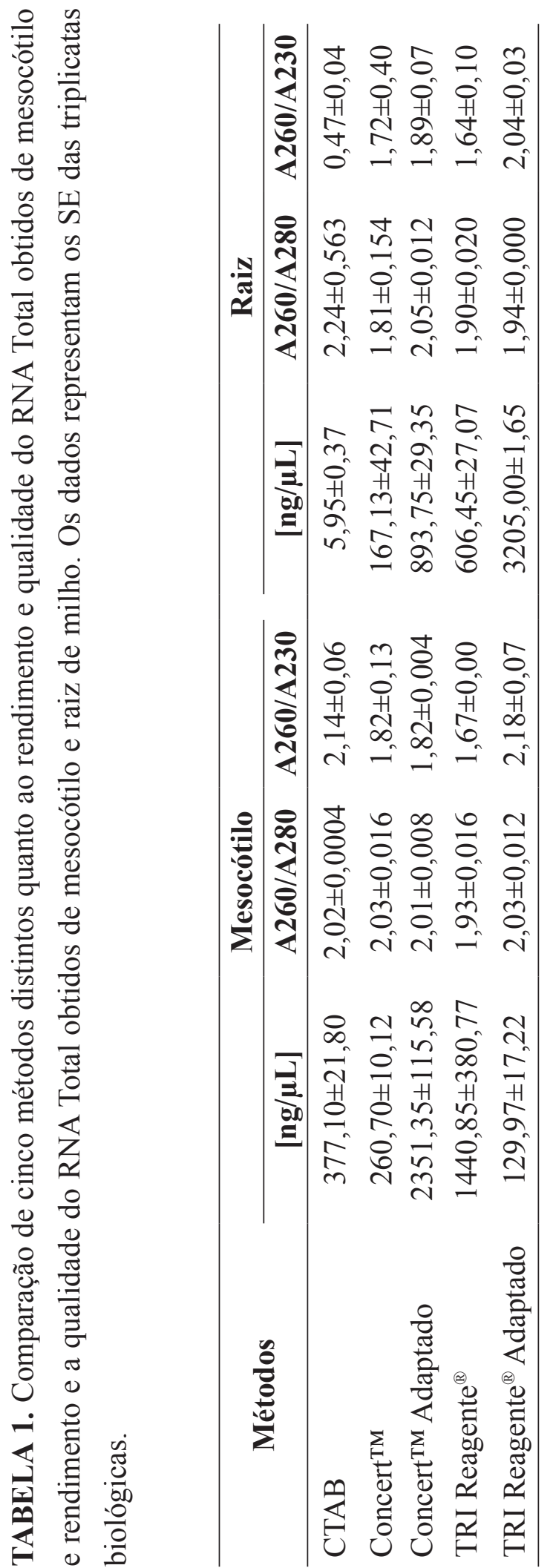


para a extração de RNA desses tecidos. Possivelmente, esses resultados se devem à presença de grandes quantidades de compostos fenólicos encontrado nos tecidos do cafeeiro, quando comparado com os do milho. Esses resultados comprovam que a eficiência de cada protocolo é altamente dependente da espécie e do tipo de tecido em estudo.
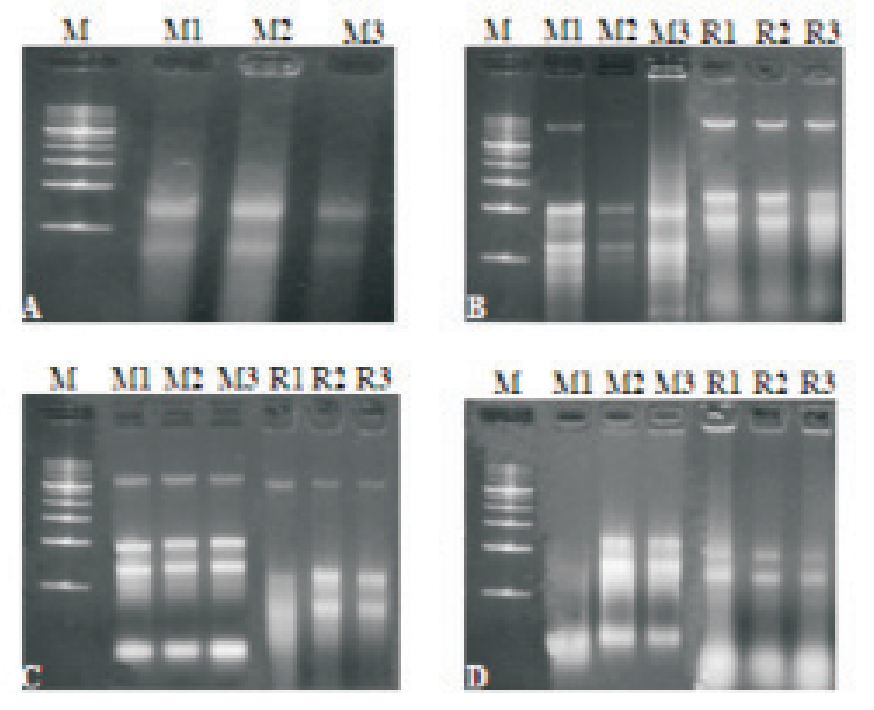

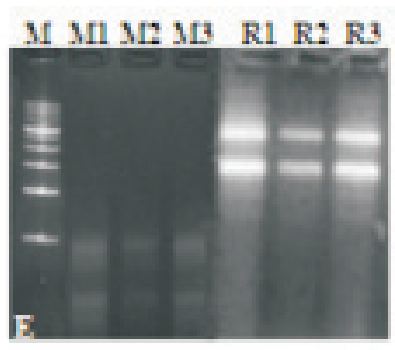
foram obtidas amostras de RNAs de qualidade satisfatória, apresentando também uma integridade das bandas $28 \mathrm{~S}$ e $18 \mathrm{~S}$ característica do rRNA, tanto para mesocótilo quanto para raiz, (Figura 1C). O método CTAB, quando utilizado em raiz, devido à quantificação extremamente baixa, não foi analisado via gel de eletroforese.

FIGURA 1. Gel de agarose 1,2\% corado com brometo de etídeo. A - Extração de RNA pelo método CTAB microextração; B - Extração de RNA pelo método Concert ${ }^{\mathrm{TM}}$ Invitrogen; C - Extração de RNA pelo método Concert ${ }^{\mathrm{TM}}$ Adaptado; D - Extração de RNA pelo método TRI Reagente ${ }^{\circledR}$ Sigma; E - Extração de RNA pelo método TRI Reagente ${ }^{\circledR}$ Adaptado. M - Marcador molecular de $1 \mathrm{~Kb}$; M e R - Tecidos de milho; 1-3: Repetições Biológicas; M (1-3): Mesocótilo; R (1-3): Raiz. 
Apresença de determinadas substâncias na composição dos métodos de extração, o tipo de tecido e modificações nos protocolos interferem na qualidade dos resultados.

Contudo, para ambos os tecidos estudados (mesocótilo e raiz), o método de extração de RNA que apresentou melhores resultados foi o Concert $^{\mathrm{TM}}$ adaptado, uma vez que ele propiciou melhor qualidade do RNA, bem como um rendimento satisfatório desse componente para posteriores estudos de expressão gênica.

\section{Agradecimentos}

À Coordenação de Aperfeiçoamento de Pessoal de Nível Superior, ao Conselho Nacional de Desenvolvimento Científico e Tecnológico, à Embrapa Milho e Sorgo e à Fundação de Amparo à Pesquisa de Estado de Minas Gerais o auxílio financeiro.

\section{Literatura Citada}

ASIF, M.; TRIVEDI, P.; SOLOMOS, T.; TUCKER, M. Isolation of high-quality RNA from apple (Malus domestica) fruit. Journal of Agricultural and Food Chemistry, Washington, v. 54, n. 15, p. 5227-5229, 2006.

AZEVEDO, H.; LINO-NETO, T.; TAVARES, R.M. An improved method for high quality RNA isolation from needles of adult maritime pine trees. Plant Molecular Biology Reporter, Athens, v. 21, n. 4, p. 333-338, 2003.

CARDillo, A. B.; GiUlietTi, A. M.; MARCONI, P. L. Analysis and sequencing of h6hmRNA, last enzyme in the tropane alkaloids pathway from anthers and hairy root cultures of Brugmansia candida (Solanaceae).

Electronic Journal of Biotechnology, Cambridge, v. 9, n. 3, p. 196-198, 2006.

CHANG, S.; PURYEAR, J.; CAIRNEY, J.A simple and efficient method for isolating RNA from pine trees. Plant Molecular Biology Reporter, Athens, v. 11, n. 2, p. 113-116, 1993.

CHOMCZYNSKI, P.; SACCHI, N. Single-step method of RNA isolation by acid guanidium thiocyanate-phenolchloroform extraction. Analytical Biochemistry, New York, v. 162, n. 1, p. 156-159, 1987.

DAL CIN, V.; DANESIN, M.; RIZZINI, F. M.; RAMINA, A. RNA extraction from plant tissues: the use of calcium to precipitate contaminating pectic sugars. Molecular Biotechnology, Totowa, v. 31, n. 2, p. 113119, 2005.

GEUNA, F.; HARTINGS, H.; SCIENZA, A. A new method for rapid extraction of high quality 
RNA from recalcitrant tissues of grapevine. Plant Molecular Biology Reporter, Athens, v. 16, n. 1, p. 61-67, 1998.

JAAKOLA, L.; PIRTTILA, A. M.; HALONEN, M.; HOHTOLA, A. Isolation of high quality RNA from bilberry (Vaccinium myrtillus L.) fruit. Molecular Biotechnology, Washington, v. 19, n. 2, p. 201-203, 2001.

KOMJANC, M.; FESTI, S.; RIZZOTTI, L.; CATTIVELLI, L.; CERVONE, F.; LORENZO, G. de. A leucine-rich repeat receptor-like protein kinase (LRPKm1) gene is induced in Malus x domestica by Venturia inaequalis infection and salicylic acid treatment. Plant Molecular Biology, Athens, v. 40, n. 6, p. 945-957, 1999.

LOGEMANN, J.; SCHELL, J.; WILLMITZER, L. Improved method for isolation of RNA from plant tissue. Analytical Biochemistry, New York, v. 163, n. 1, p. 1620, 1987.

MEISEL, L.; FONSECA, B.; GONZÁLEZ, S.; BAEZAYATES, R.; CAMBIAZO, V.; CAMPOS, R.; GONZALEZ, M.; ORELLANA, A.; RETAMALES, J.; SILVA, $H$. A rapid and efficient method for purifying high quality total RNA from peaches (Prunus persica) for functional genomics analyses.
Biological Research, Santiago, v. 38, n. 1, p. 83-88, 2005.

MANNING, K. Isolation of nucleic acid from plants by differential solvent precipitation. Analytical Biochemistry, New York, v. 195, n. 1, p. 45-50, 1991.

PAULA, M. F. B. de. Identificação e caracterização parcial dos genes Sepallata em café arábica. 2009. 102 f. Dissertação (Mestrado em Fisiologia Vegetal) Universidade Federal de Lavras, Lavras.

SALZMAN, R. A.; FUJITA, T.; ZHUSALZMAN, K.; HASEGAWA, P. M.; BRESSAN, R. A. An improved RNA isolation method for plant tissues containing high levels of phenolic compounds or carbohydrates.

Plant Molecular Biology Reporter, Athens, v. 17, n. 1, p. 11-17, 1999.

SUZUKI, M.; KETTERLING, M. G.; MCCARTY, D. R. Quantitative statistical analysis of cis-regulatory sequences in ABA/ VP1- and CBF/DREB1-regulated genes of arabidopsis. Plant Physiology Review, Washington, v. 139, n. 1, p. 437-447, 2005.

VALENZUELA-AVENDAÑO, J. P.; ESTRADA-MOTA, I. A.; LIZAMA, U. C. G.; SOUZA-PERERA, R.; VALENZUELA- 
SOTO, E. M.; ZÚÑIGA-AGUILAR, J. J. Use of a simple method to isolate intact RNA from partially hydrated Selaginella lepidophylla plants. Plant Molecular Biology Reporter, Athens, v. 23, n. 2, p. 199-201, 2005.
ZAMBONI, A.; PIERANTONI, L.; FRANCESCHI, P. de. Total RNA extraction from strawberry tree (Arbutus unedo) and several other woody-plants. Journal of Biogeosciences and Forestry, Bologna, v. 1, n. 1, p. 122-125, 2008. 